\title{
Deprofessionalisation as a Performance Management Dysfunction: The Case of Inclusive Education Teachers in Russia
}

\author{
Mariia Rubtcova ${ }^{1}$, Oleg Pavenkov ${ }^{2}$, Vladimir Pavenkov ${ }^{2}$, Natalia Martianova ${ }^{3} \&$ Denis Martyanov ${ }^{4}$ \\ ${ }^{1}$ Faculty of Sociology, Saint Petersburg State University, Saint Petersburg, Russia \\ ${ }^{2}$ Saint Petersburg State University of Cinema and Television, Saint Petersburg, Russia \\ ${ }^{3}$ Herzen State Pedagogical University, Saint Petersburg, Russia \\ ${ }^{4}$ Faculty of Political Science, Saint Petersburg State University, Saint Petersburg, Russia \\ Correspondence: Mariia Rubtcova, Department of Social Management and Planning, Faculty of Sociology, Saint \\ Petersburg State University, 7-9, Universitetskaya nab., Saint Petersburg, 199034, Russia. Tel: 8-921-381-1889. \\ E-mail: m.rubtsova@spbu.ru
}

Received: March 22, 2015 Accepted: April 8, 2015 Online Published: June 5, 2015

doi:10.5539/ass.v11n18p339

URL: http://dx.doi.org/10.5539/ass.v11n18p339

\begin{abstract}
This article examines two important phenomena related to the performance-based assessment challenges of the teaching profession: deprofessionalisation and dealtruisation. Theoretical analyses have allowed us to draw conclusions concerning the trends in the teaching profession, its relations with dealtrusation and deprofessionalisation, and the various contradictions associated with the performance of professionals in their social role during performance-based reforms. Based on Merton's methodology of altruism research-and partly debating with modern approaches to deprofessionalisation-we have chosen inclusive education teachers as a special group, which under the influence of dysfunctional performance management requirements became dealtruistic to the greatest extent. In this study, convenience sampling and in-depth interviews have been used. The sample consisted of 57 inclusive education teachers. Data processing was carried out with the use of Corpus Tool 3.1.14. As a result, based on the typology of altruistic behaviour, as introduced by Merton, we have identified the type of behaviour amongst teachers, which leads us to the formulation of educational and school policy recommendations. The authors suggest that a more in-depth study of the experience of other countries will help with the development of a more optimal version of educational reforms and its continuation.
\end{abstract}

Keywords: performance management, management dysfunction, teachers' deprofessionalization, dealtruisation, inclusive education, performance-based educational reforms

\section{Introduction}

All the nuances of interpersonal and intergroup relations take place in a professional environment. In addition, the profession, as a particular social group, interacts with other groups, and society as a whole, providing a formal or latent influence (Merton, 1982). The study into changes in professions during the performance-based reforms is an urgent need in the context of social sciences (Downs, 1985; Cuban, 1992; Darling-Hammond \& McLaughlin, 1995; Barrett, 2009; Lundstrom, 2012; Karami, 2014). Initially, the performance management was extremely concerned about the growth of professionalism (Downs, 1985). Further, it was noticed that the performance management could lead to deprofessionalisation (Beck \& Young, 2005). Then deprofessionalisation was conceptualised as an actual and timeliness topic (Andrews \& Waerness, 2011; Busch, 2012; Al-Zboon, Alkhatib, \& Alkhawaldeh, 2015).

However, despite the centrality of ideas of professionalism to performance management prescriptions, our knowledge of how professionalism, altruism and performance management interact remains limited. A serious amount of research has studied the effects of professionalism, professional environment, deprofessionalisation, altruistic behavior, neo-liberal reforms and performance management separately; we are lacking research that can examine this relation explicitly. Thus, this article examines two important phenomena related to the topic: institutional altruism and deprofessionalisation (Toren, 1975; Germov, 1995), as based on Merton's methodology of altruism research. 
The problem of institutional altruism is one of the central issues of sociology of professions (Merton, 1982). Institutional altruism is an important feature as a returning benefits mechanism to those who help. This happens all the time at the human relationships level (for example: in the case of mutual friendships). Differences between altruism and institutional altruism are as follows:

- Altruism: The benefits returned from the original recipient to the donor.

- Institutional altruism: To secure a donor from other individuals in the social system of which they are a part (Merton, 1982).

Parsons draws attention to the fact that the most significant differences in the types of human motivation are a dichotomy between 'altruistic' and 'egoistic' motives (Parsons, 1939). According to this, dichotomy correlates with the identification of specific motives in different spheres of human activity: a businessman is seen as selfishly pursuing his own interest, whilst professional people altruistically serve the interests of others (Parsons, 1939).

Merton (1982) considers not so much altruistic professionals but the process of institutionalisation of altruism in society. In this regard, the task of sociology is explaining the structural basis of altruistic actions, which implies behaviour and helping others at the expense of attendant (Merton, 1982). It is implied that the behaviour assistant receives less profit than if he/she did not behave altruistically (Merton, 1982). Moreover, this phenomenon is not limited to material benefits, but includes other parameters, such as prestige, respect, power (Merton, 1982).

Therefore, deprofessionalisation leads to dealtruisation and vice versa. The term 'altruisation' was introduced by Sorokin (1967). According to Sorokin's point of view, individual altruisation is possible only through altruisation by groups or institutions and vice versa, altruisation institutions or groups is possible only through altruisation their members. Therefore, dealtruisation is also closely related to the condition institutions of society. Group and institution dealtruisation is possible only through the dealtruisation of their members. In the institutions and groups crisis, the crisis of individual altruisation also takes place. The analysis focused on dealtruisation as a crisis of altruism in professions. Professional dealtruisation is characterised by a decline in the importance of altruistic behaviour in professional activities (Rubtcova \& Martianova, 2015).

Merton (1982) analysed professional altruism in the context of the process of the institutionalisation of altruism in society; institutional altruism focuses on the alternatives of action by which social structure increase the probability of choosing an altruistic action. Merton developed a typology of altruistic behaviour (see Table 1).

Table 1. Typology of altruistic behaviour (Merton, 1982)

\begin{tabular}{cccc}
\hline $\begin{array}{c}\text { The motives of the person who } \\
\text { helps }\end{array}$ & $\begin{array}{c}\text { Consequences for a person who } \\
\text { was helped }\end{array}$ & $\begin{array}{c}\text { The consequences for the person } \\
\text { who helps }\end{array}$ & Type of action \\
\hline Altruistic & benefit & benefit & Reciprocal altruism \\
Altruistic & benefit & no benefit \\
Altruistic & no benefit & benefit & Pultruism \\
Altruistic & no benefit & no benefit & Trivial altruism \\
Egoistic & benefit & benefit & Enlightened egoism \\
Egoistic & benefit & no benefit & Unintentional altruism \\
Egoistic & no benefit & benefit & Pure egoism \\
Egoistic & no benefit & no benefit & Ineffective behaviour \\
\hline
\end{tabular}

Table 1 clearly shows that there are several types of egoistic and altruistic behaviour, and that the motives of helping can be different and not always selfless.

The norm of altruism requires professionals to do everything in their power to satisfy customers-even at the expense of their own interests; that is, according to the standard of altruism, professionals should do more than is required of them within their professional duty (Merton, 1982).

We believe that altruism is the basis of professional work. Altruistic requires a priori characteristic of the majority of professionals that distinguishes them from other groups (businessmen, officials, etc.) (Rubtcova, Martyanov \& Martyanova, 2013; Pavenkov, Pavenkov \& Rubtcova, 2015). Therefore, the term 'dealtruisation', in relation to professionals, indicates the reduced importance of altruistic behaviour in their professional activities (Rubtcova \& Martianova, 2015). The reduced importance of altruistic behaviour is an important factor in the crisis of the profession as a social institution.

Performance-based reforms have been introduced widely in the Russian public sector during the 2000s, but reform efforts have been promoted mainly through formal orders and commands, rather than in-depth understanding (Evstatchic \& Menshikova, 2014). The general result of permanent reforms, the content of which 
remains unclear is the loss of guidability. In accordance with the work of Etzioni (1979), guidability enables people to work together with high efficiency, and is based on common values. The total loss of understanding of the reform goals has resulted in a serious decline in professional groups influence (Rubtcova, Martianov \& Martianova, 2013; Rubtcova \& Martianova, 2015). The destruction of the values of professional groups destroys the professional standards and has questioned the need for altruism (Rubtcova \& Martianova, 2012).

In an effort to study the relationship between deprofessionalisation and dealtruisation, we refer to a special group of professionals: teachers of inclusive education. These professionals carry out one of the most socially significant activities. Their job duties are associated with altruistic behaviour, namely care, compassion, sympathy, mercy, and caring for weak and sick people.

Since altruisation of institutions or groups is possible only through altruisation of their members (Sorokin, 1967), it is logical to assume that the dealtruisation of the inclusive teachers' profession is possible through the dealtruisation of individual members.

Specifically, the current study attempts to answer the following research questions:

- Is the deprofessionalisation`s trend relevant in modern Russia?

- What is the relationship between dealtruisation and deprofessionalisation?

\section{Method}

\subsection{Research Design}

This study involves the use of the following methods:

- In-depth interviews of inclusive teachers: the interviews attempted to explore the different attitude to altruism in the professional sphere and different parameters of deprofessionalisation. The data were collected through interviews with inclusive teachers, which helped us to draw a large picture of such phenomenon as institutional altruism and deprofessionalisation.

- There was the analysis of the interview transcripts using Corpus tool 3.1.14. Merton's table (see Table 1) formed the basis of the analysis of altruistic behaviour of inclusive teachers.

\subsection{Population and Participants}

The research was carried out in September-November 2012. In the study, a convenience sampling approach was utilised. The sample comprised 57 inclusive education teachers (all of whom were women aged 30-55 years old) Amongst the 57 teachers, 11 were working in correctional schools and 46 in correctional classes of ordinary (main) schools. All of them were familiar with the system of inclusive education because they had common classes, including healthy children and children with disabilities, and applied some of its elements in their daily practice. Some of them (15\%) participated in special grant programmes and training courses on inclusive education.

\subsection{Instrumentation}

In the study, we created a topic guideline in-depth interviews with the use of open-ended questions for respondents, which allowed them to express their opinion in a free form. Special attention was paid to ensuring the anonymity of respondents. The topic guide dealt with various aspects of the professional activity of respondents: their personal experience in dealing with children with disabilities, their professional goals and objectives, as well as their personal career ambitions and plans. The questions were aimed at identifying the propensity of respondents to the altruistic behaviour, as well as their personal attitude towards altruism in their daily professional practice. Some issues were associated with a common vision amongst the respondents, their future as professionals and their relationship to the problem of deprofessionalisation in modern society. The transcripts of the in-depth interviews are processed with the use of Corpus Tool 3.1.14.

\subsection{Procedures}

In order to achieve the aims of the present study, the following procedures were taken:

- The researchers conducted a theoretical and methodological analysis of the phenomena 'dealtruisation' and 'deprofessionalisation'.

- The researchers analysed the usage of the terms 'profession' and 'professional' in Russian National Corpus and identified trends in the development of the concept 'deprofessionalisation'.

- The researchers conducted in-depth interviews with 57 teachers of inclusive education. 
- The transcripts of the in-depth interviews were processed with the use of Corpus Tool 3.1.14 in an effort to identify the ratio of the altruistic and egoistic behaviours of the respondents.

\subsection{Ethical Considerations}

Taking ethical considerations into account, we used an informed consent form to the participants. All participants were initially contacted, asked to participate in the study and informed about the purpose and aims of the research. Participant consent to participate was gained. They were assured of the anonymity of their responses through the use of pseudonyms to report the results, and were guaranteed of the confidentiality of collected data. This study was conducted in line with the Professional Ethical Code of Sociologists by the Russian Society of Sociologists (RSS).

\section{Trends in the Development of the Concept 'Deprofessionalisation': Preliminary Corpus-Based Study}

To explore the trend of deprofessionalisation in Russia, we analysed the use of the words 'profession' and 'professional' in the Russian national corpus (2015). Deprofessionalisation in Russia developed later than in Western countries.

As has been shown through our analysis of the literature, the problem of deprofessionalisation emerged in the West in the 1970s-1980s (Toren, 1975; Lionel, 1983; Haug, 1973). At this time, Russia, on the other hand, had a rise in the interest of professions and professionalism. This idea is demonstrated by the frequency of use of the words 'profession' and 'professional' in the Russian national corpus (2015). These graphs show the popularity of these words in Russian speech in the period 1800-2012 (see Figures 1-2).

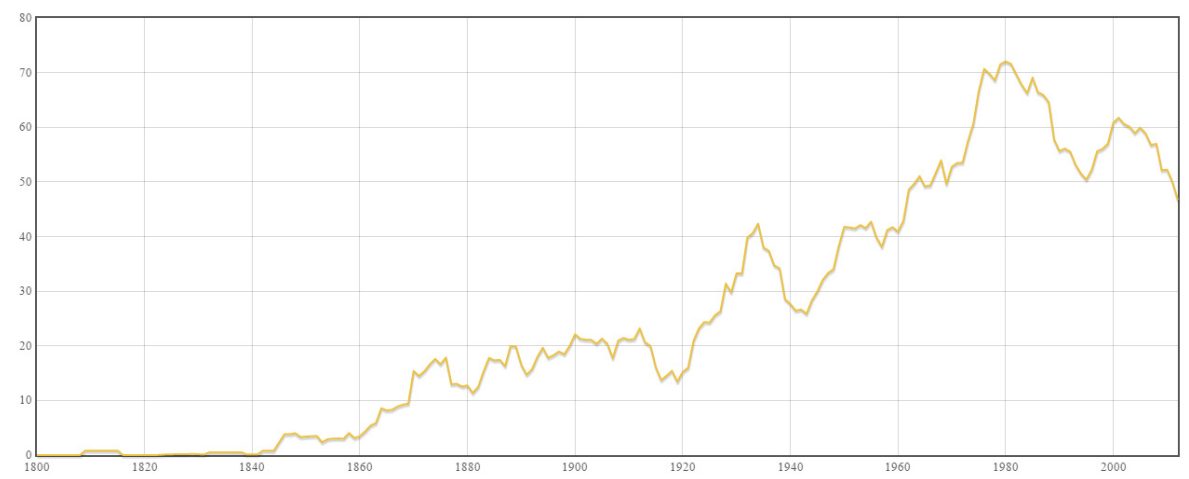

Figure 1. The use of the word 'profession' in Russian National Corpus in 1800-2012

As we can see in Figure 1, the peak use of the word 'profession' took place in 1960-1980. At that time, many new professions appeared and developed in Russia. However, the frequency of the use of the word 'profession' began to decrease. New growth began in the mid 1990-ies, when the economic situation improved. The start of large-scale performance-based reforms in the early 2000 s overturns the concept 'profession'.

On the other hand, the concept of 'professional' is seen to have experienced a different time of development. Following the profession being established as an important element of social life, the Russian language reflected a new understanding of 'professional' as 'high-quality employment' (see Figure 2).

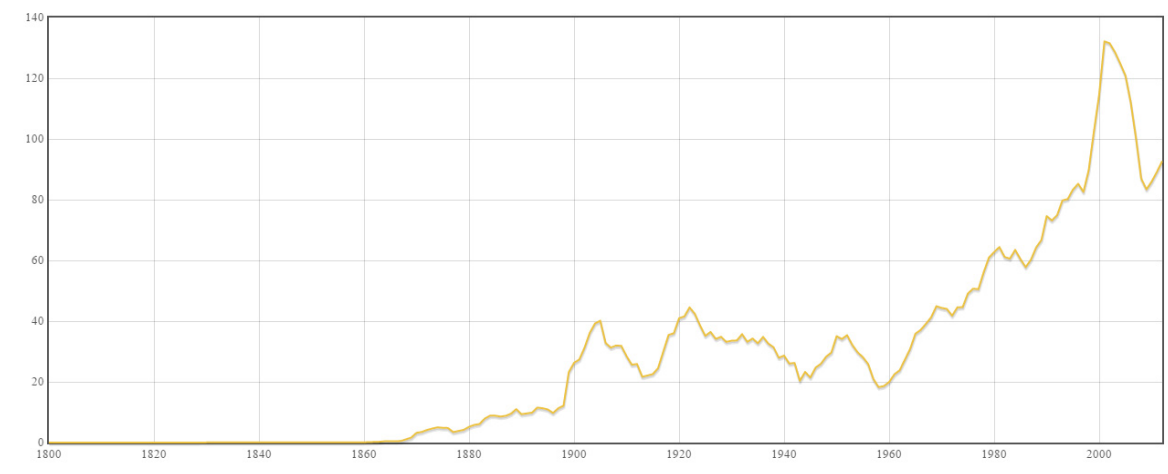

Figure 2.The use of the word 'professional' in Russian National Corpus in 1800-2012 
As shown in the graph, there was a sharp increase in 2000, but then a decline (Figure 2). Subsequent figures (Figures 3-4) reflect the huge decline of both words' use since 2000.

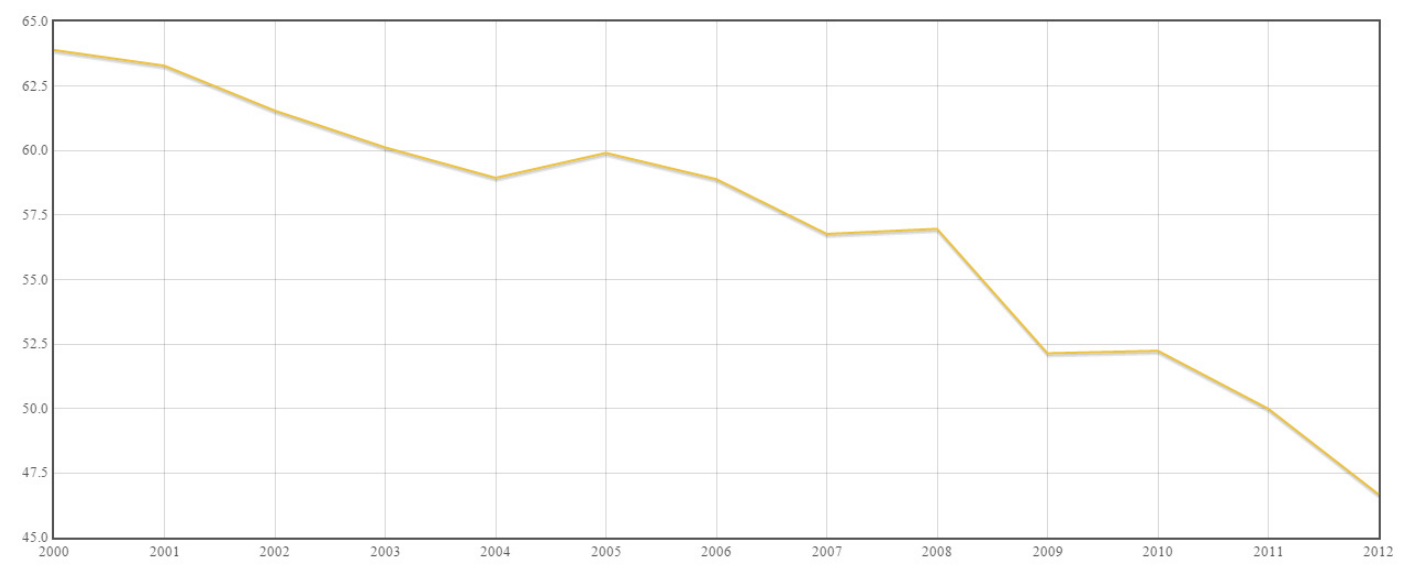

Figure 3. The use of the word 'profession' in Russian National Corpus in 2000-2012

The use of the word 'professional' showed very slight increase during the election period when active reforms were suspended (Figure 4).

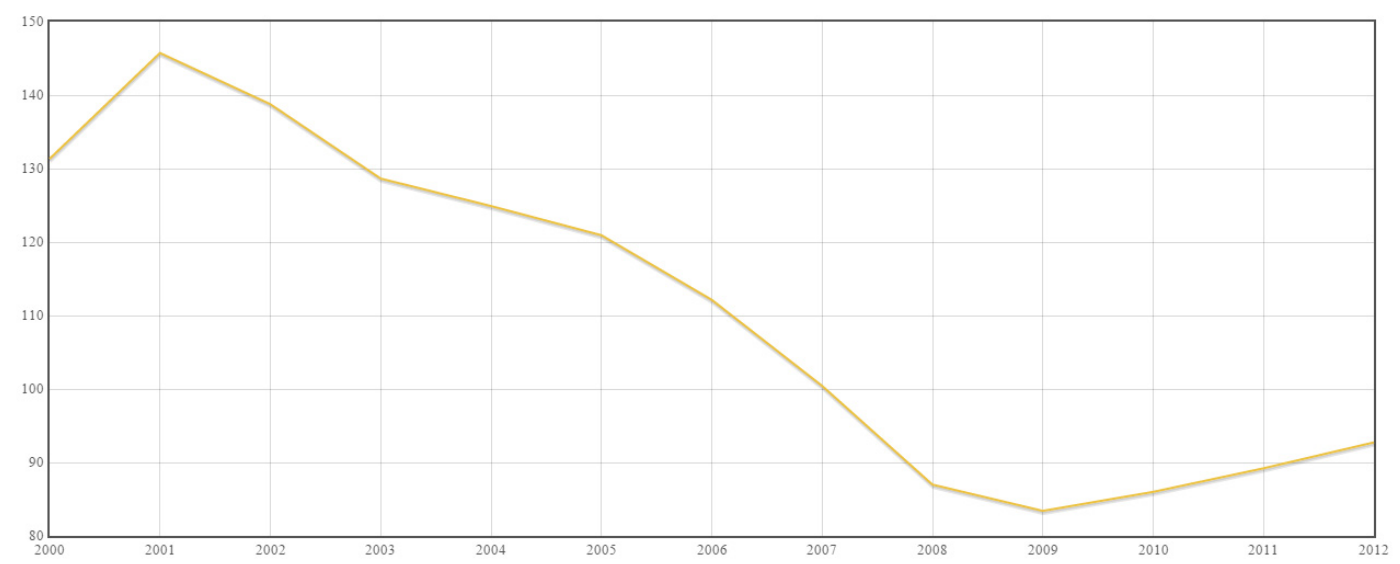

Figure 4. The use of the word 'professional' in Russian National Corpus in 2000-2012

Thus, we see a certain decrease of interest in professionalism, which coincides with performance-based reforms: the use of the words 'profession' and 'professional' consistently increase and reach a peak in 2000, after which there has been a steady decline in the popularity of these terms.

\section{Results}

Applied research has led us to the following results: the vast majority of respondents (78\%) said that their daily professional activities are not associated in any way with altruistic motives. As such, the value of altruism is extremely low, and is not personally of any significant importance or professional interest. Inclusive teachers are busy performing their daily professional duties, and rarely configured on something more than this: for example they said: 'In our work, excessive altruism is not needed' or 'Our work is essentially one continuous altruism, why do we need more?' For them, working with children with disabilities is a common job for money and professional status. Some of them (15\%) are interested in their own career. For this category of respondents, inclusive education provides opportunities for their selfish purposes, i.e. grants, internships, foreign programmes and projects. For example, one of them said: 'In principle we are ready to deal with anything surcharge and inclusive education too'. Moreover, those professionals who demonstrate a commitment to altruism can be considered career-oriented professionals as 'losers': for example, one of them said: 'They are simply losers who couldn't find a decent application of their efforts'. These respondents also found no altruistic motives with their daily professional activities. 
At the end of in-depth interviews, we asked the informants what type of altruism or selfishness characterises their behaviour. Their response is also taken into account in the analysis. If we analyse the data obtained from the transcripts of the in-depth interviews, we can see that even the seemingly altruistic behaviour of respondents actually is not.

As can be seen from Table 2-which was compiled on the basis of Merton's table (see Table 1) - the largest number of respondents demonstrate pseudo-altruistic behaviour (50.8\%) and reciprocal altruism (21\%); they are equally distant from points such as 'pure altruism' (8.7\%) and 'trivial altruism' (7.5\%). The benefits for inclusive teachers may be grants and bonuses for participating in various educational programmes. Thus, we can state, with confidence, that the purely altruistic actions of professionals are not an important part of their values.

Table 2. The ratio of egoistic and altruistic types of respondent's behaviour

\begin{tabular}{ccc}
\hline Feature & Egoism & Altruism \\
\cline { 2 - 3 } & Percent \\
\hline Appraisal type & $\mathrm{N}=7$ & $\mathrm{~N}=50$ \\
\hline Egoism & $12,00 \%$ & $0,00 \%$ \\
Altruism & $0,00 \%$ & $88,00 \%$ \\
\hline Egoism-type & $\mathrm{N}=7$ & $\mathrm{~N}=0$ \\
\hline Enlightened egoism & $5,20 \%$ & $0,00 \%$ \\
Unintentional altruism & $3,40 \%$ & $0,00 \%$ \\
Pure egoism & $1,70 \%$ & $0,00 \%$ \\
Ineffective behaviour & $1,70 \%$ & $0,00 \%$ \\
\hline Altruism-type & $\mathrm{N}=0$ & $\mathrm{~N}=50$ \\
\hline Reciprocal altruism & $0,00 \%$ & $21,00 \%$ \\
Pure altruism & $0,00 \%$ & $8,70 \%$ \\
Pseudo-altruism & $0,00 \%$ & $50,80 \%$ \\
Trivial altruism & $0,00 \%$ & $7,50 \%$ \\
\hline
\end{tabular}

Should be said, that our initial study focused on altruism and we expected judgments that are more positive. Therefore, we needed clarification of the guide, which included the questions about the reasons for such a low level of altruism. We supplemented guide after the first three interviews.

Answers also show the dominant values in the situation of losing contact with a professional environment or destroying of the normal professional environment as the result of performance-based assessment dysfunction. There are the most detailed answers: 'Our attestation does not take into account the work with children with disabilities in the classroom', 'If we are going to give disabled children a lot of time, other students will not get knowledge, and we will have problems with the indicators for attestation of teachers 'category', 'We have a little time, all children need to prepare for the state exam. If students will pass the state exam bad, it is considered as guilt and responsibility of the teacher. This has consequences in assessing the effectiveness of my work.' Even such powerful arguments as saving the fate of children with disability are not always effective in conditions of deprofessionalisation generated the new performance-based assessment system. In fact, if we asked any questions about the assessment and attestation system, all informants accused its inability to properly perform their professional functions.

We can accept that promoting altruistic behaviour is the main activity of professional communities, as the lack of focus on altruism is an important indicator of deprofessionalisation. On the example of inclusive teachers, it can be argued that the crisis of the profession is directly related to dealtruisation, i.e. the loss of desire for altruistic action in everyday professional practice. This may be a reliable indicator of the problems that may be further concretised in terms of their real source.

\section{Discussion}

Many researchers do not associate deprofessionalisation with dealtruisation, and do not pay special attention to the study of altruism in the professions. Some of them are studying the phenomenon of deprofessionalisation, which may be related to other factors, such as the knowledge base and the service ideal (Toren, 1975), the democratisation of the professional institution (Lionel, 1983), proletarianisation (Germov, 1995), 'the loss of monopoly over knowledge, public belief in their service ethos, and expectations of work autonomy and authority over the client' (Haug 1973:197) and consumer revolution (Levine, 1988). 
Altruism, in the context of the professions, is mentioned infrequently, such as as a myth (Seddon, 1997) or to emphasise its unimportance compared with other factors (Timmermans \& Hyeyoung, 2010).

However, in Russia, the high status of professionals and their public respect has always been based on the ability of a professional (teacher, doctor, priest etc.) in regard to altruistic actions. Altruism has long been inseparable from the professionalism from the viewpoint of the average person and society. In this sense, Merton's theory of institutional altruism is relevant for professionals in Russia.

Therefore, we can say that the modern situation witnesses the dealtruisation of professionals promoting deprofessionalisation. These factors are closely related. Of course, it would be illusory to believe that professionals, including in the social sphere, automatically interested in altruistic activities. The humanistic potential of professionals, unfortunately, levelled the job requirements of employees, as well as neo-liberal criteria for evaluation. Obviously, special management measures are required in order to revive the humanistic basis of professional practice.

\section{Conclusion}

The problems of educational reform are usually discussed from the point of view of teachers' resistance to change (Evans, 1996); however, as shown in the article, this level of resistance can have more in-depth and dangerous consequences, such as when the deprofessionalisation and dealtruisation of teaching employees started. The example of one of the most humanistically oriented and altruistic groups has been given: that of inclusive education teachers. In the Russian context, a spiritual (and possibly religious) matter is working with disabled, which is mediated by deep spiritual values. Soviet pedagogy abandoned religious ideas; however, key attention was directed towards the moral values of teachers. As we can see from the results of our study, a professional community that supports these ideals could not adapt to neo-liberal challenges, and had set teachers in the face of self-selection in unfavorable conditions of tough performance appraisal system, which is not able to take into account their real pedagogical achievement and assistance to children with disabilities. Altruism and the support of teaching professionals pride is not performance management system priority. The situation threatens serious social upheaval as students and parents can become victims and opponents of neo-liberal educational reform. Past autumn 2014 meetings of parents against the reform of correctional (special) education and its replacement with inclusive education were witnessed in many Russian cities. This is a further confirmation of social contradictions caused by the neo-liberal and performance-based educational reform. As we can see, the direct transfer of Western experience does not give positive results. This conclusion is supported by other solid studies, describing the situation in the non-Western world (e.g., Karami, 2014).

However, the neo-liberal and performance-based educational reform is a response to serious economic challenges; therefore, the rejection of its holding will not allow students to prepare for their future life and job search in a competitive labour market. The typical response to this situation is the declaration on the common search for a new 'step by step' way that will take into account both: the demands of globalisation and the requirements of national identity and deep culture. Such a way is not easy: it requires an active exchange of views, which is an attempt to avoid isolation, but which requires that the culture is not destroyed. The very attempt to develop such a programme is an important contribution to this acute problem faced by many countries in the world. The authors suggest a deeper study of the experience of other countries-especially the BRICS countries - will help to develop a more optimal version of the educational reforms' continuation.

\section{References}

Al-Zboon, E., Alkhatib, A., \& Alkhawaldeh M. F. (2015). Quality of Life of Teachers of Children with Disabilites. Mediterranean Journal of Social Sciences. http://dx.doi.org/10.5901/mjss.2015.v6n2s1p40

Andrews, T., \& Wærness K. (2004). Deprofessionalisering av helsesøsteryrket? Sosiologisk Tidsskrift, 12(4), 325-341.

Andrews, T., \& Waerness, K. (2011). Deprofessionalization of a female occupation: Challenges for the sociology of professions. Current Sociology, 59(1), 42-58. http://dx.doi.org/10.1177/0011392110385969

Barrett, B. D. (2009). No Child Left Behind and the Assault on Teachers' Professional Practices and Identities. Teaching and Teacher Education, 25(8), 1018-25. http://dx.doi.org/10.1016/j.tate.2009.03.021.

Beck, J. (2002). The sacred and the profane in recent struggles to promote official pedagogic identities. British Journal of Sociology of Education, 23(4), 616-626.

Beck, J., \& Young, M. F. D. (2005). The assault on the professions and the restructuring of academic and professional identities: a Bernsteinian analysis. British Journal of Sociology of Education, 26(2), 183-197. 
Busch, N. (2012). Deprofessionalisation and informality in the market for commoditised care. In R. A. Sollund (Ed.), Transnational Migration, Gender and Rights (Vol. 10, pp. 53-75). Bingley: Emerald Group Publishing Ltd.

Correia, T. (2011). An open-system approach to medical professionalism: a controversy within the sociology of professions. Interface - Comunicação, Saúde, Educação, 15(38), 779-792. http://dx.doi.org/10.1590/s141432832011000300013

Cuban, L. (1988). The managerial imperative and the practice of leadership in schools. New York, NY: Suny.

Cuban, L. (1992). Managing dilemmas while building professional communities. Educational Researcher, 21(1), 4-11.

Darling-Hammond, L., \& McLaughlin, M. W. (1995). Policies that support professional development in an era of reform. Phi Delta Kappan, 76(8), 597-604.

Darling-Hammond, L., Wei, R. C., Andree, A., Richardson, N., \& Orphanos, S. (2009). Professional learning in the learning profession: A status report on teacher development in the United States and Abroad. Stanford University, CA: The National Staff Development Council and the School Redesign Network.

Delmas, C. (2006). Sociology of health: Institutions, professions and diseases. Homme, (179), 290-291.

Demaziere, D. (2011). The sociology of professions. Sociologie Du Travail, 53(3), 411-413.

Downs, J. (1985). The Individual within the System - Performance Management. Educational Management Administration \& Leadership, 13(2), 99-105. http://dx.doi.org/10.1177/174114328501300205.

Etzioni, A. (1979). Beyond Integration, Toward Guidability. Syracuse University Press.

Evans, R. (1996). The human side of school change: Reform resistance and the real life problems of innovations. San Francisco, SF: Jossey-Bass.

Evstatchic, S., \& Menshikova, G. (2014). Publicity culture in Russia: history and current estimates. International Scientific Conference. Fourth Kareevskie reading. History and theory of sociology. St.Petersburg

Faulconbridge, J. R., \& Muzio, D. (2012). Professions in a globalizing world: Towards a transnational sociology of the professions. International Sociology, 27(1), 136-152. http://dx.doi.org/10.1177/0268580911423059

Germov, J. (1995). Medi-fraud, managerialism and the decline of medical autonomy: deprofessionalization and proletarianisation reconsidered. Journal of Sociology, 31(3), 51-66 http://dx.doi.org/10.1177/14407833 9503100305

Groenewegen, P. P. (2006). Trust and the sociology of the professions. European Journal of Public Health, 16(1), $3-4$.

Groulx, L. (1983) Deprofessionalisation of Social Service: Demands of Democracy or Pretensions to a New Power. International Social Work, July 26, 38-44.

Haug, M. (1973). Deprofessionalisation: An Alternative Hypothesis for the Future. In Halmos (Ed.), Professionalisation and Social Change (pp. 195-211).

Hellberg, I. (1999) Altruism and utility: Two logics of professional action. In I. Hellberg, M. Saks, \& C. Benoit (Eds.), Professional Identities in Transition: Cross-Cultural Dimensions. Södertälje: Almquist and Wiksell International.

Karami, A. R. (2014). Facing the Challenges of Educational Reform in the Arab World. Journal of Educational Change, 15(2), 179-202. http://dx.doi.org/10.1007/s10833-013-9225-6

Korabliova, G. B. (2013). Making of approaches to sociology of professions in Russia. Sotsiologicheskie Issledovaniya, (1), 109-117.

Levine, L. W. (1988). Highbrow-Lowbrow: The Emergence of Cultural Hierarchy in America. Cambridge: Harvard University Press.

Lundstrom, U. (2012). Teachers' Perceptions of Individual Performance-Related Pay in Practice: A Picture of a Counterproductive Pay System. Educational Management Administration \& Leadership, 40(3), 376-391. http://dx.doi.org/10.1177/1741143212436954

Mansurov, V. A., \& Yurchenko, O. V. (2009). Sociology of professions (history, methodology, research practices). Sotsiologicheskie Issledovaniya, (8), 36-46.

Martianova, N. A., Rubtcova, M. V., \& Pavenkov, O. V. (2015). Robert K. Merton's and Pitirim A. Sorokin's 
Concept 'Altruism': Conceptualisation and Operationalization for Sociological Research. Cognitive Linguistics: Cognition, Language, Gesture eJournal. Retrieved from http://ssrn.com/abstract=2575098

Martianova, N., \& Rubtcova, M. (2015). Dealtruization as a Crisis of Altruism: Theoretical Framework. Microeconomics: Welfare Economics \& Collective Decision-Making eJournal. ERN: Altruism. Retrieved from http://ssrn.com/abstract $=2577945$

Mathieu-Fritz, A. (2012). The sociology of professions. Revue Francaise De Sociologie, 53(3), 543-548.

Merton, R. K. (1940a). Major Social Institutions. Annals of the American Academy of Political and Social Science, 208, 240-241. http://dx.doi.org/10.1177/000271624020800183

Merton, R. K. (1940b). Social Control: Social Organization and Disorganization in Process. American Journal of Sociology, 45(6), 936-937.

Merton, R. K. (1957). The Role-Set - Problems in Sociological-Theory. British Journal of Sociology, 8(2), 106-120. http://dx.doi.org/10.2307/587363

Merton, R. K. (1958). The Functions of the Professional Association. American Journal of Nursing, 58(JAN), 50-54. http://dx.doi.org/10.2307/3461366

Merton, R. K. (1960). The Search for Professional Status. American Journal of Nursing, 60(5), 662-664.

Merton, R. K. (1963). Ambivalence of Scientists. Bulletin of the Johns Hopkins Hospital, 112(2), 77-85.

Merton, R. K. (1969). Behavior Patterns of Scientists. American Scholar, 38(2), 197-225.

Merton, R. K. (1982). In A. Rosenblatt, \& T. F. Gieryn (Eds.), Social Research and Practicing Professions. Cambridge, Massachusetts: Abt Books.

Merton, R. K., \& Kendall, P. L. (1946). The Focused Interview. American Journal of Sociology, 51(6), 541-557. http://dx.doi.org/10.1086/219886

Muzio, D., Brock, D. M., \& Suddaby, R. (2013). Professions and Institutional Change: Towards an Institutionalist Sociology of the Professions. Journal of Management Studies, 50(5), 699-721. http://dx.doi.org/10.1111/joms.12030

Muzio, D., Kirkpatrick, I., \& Kipping, M. (2011). Professions, organizations and the state: Applying the sociology of the professions to the case of management consultancy. Current Sociology, 59(6), 805-824. http://dx.doi.org/10.1177/0011392111419750

Parsons, T. (1937). Remarks on Education and The Professions. International Journal of Ethics, 47(3), 365-369.

Parsons, T. (1939). The Professions and Social Structure. Social Forces, 17(4), 457-467. http://dx.doi.org/10. $2307 / 2570695$

Parsons, T. (1940). What It Means To Be a Doctor. American Journal of Sociology, 45(5), 821-822. http://dx.doi.org/10.1086/218477

Pavenkov, O. V, Pavenkov, V., \& Rubtcova, M. V. (2015). The altruistic behavior: characteristic of future teachers of inclusive education in Russia. Procedia - Social and Behavioral Sciences. http://dx.doi.org/10. 1016/j.sbspro.2015.03.003

Pavenkov, O. V., Pavenkov, V., \& Rubtcova, M. V. (2015). The Concept 'Altruism' for Sociological Research: From Conceptualization to Operationalization. Cornell University Library. Computation and Language. 03/2015 arXiv: 1503.01258

Pavenkov, O. V. (2014). Contemporary Linguistic Analysis of the Concept “Love”. Studia Humanitatis, 4, 8-16. http://dx.doi.org/10.2139/ssrn.2578269

Pavenkov, O. V., Rubtcova, M. V., \& Pavenkov, V. (2015). Sorokin's Altruization Concept and Future Teachers' Attitudes towards Inclusive Education. Public Service Delivery eJournal. PSN: Education. Retrieved from http://ssrn.com/abstract $=2577208$

Pavenkova, M. V. (2001). An Institute and an Institutionality as Sociological Concepts. Vestnik St. Petersburg University. Ser. 6. Issue 3. http://dx.doi.org/10.2139/ssrn.2581550

Poudyal, C. (2015). Neo-Liberal Educational Reform and the Role of Teachers' Unions in the Context of Private Schools in Nepal: Possibility or Paralysis? Policy Futures in Education, March. http://dx.doi.org/10.1177/ 1478210315572675.

Raynaud, D. (2008). Being an architect. The virtues of indetermination. From sociology of a profession to 
sociology of a professional work. Sociologie Du Travail, 50(1), 128-129. http://dx.doi.org/10.1016/j. soctra.2007.12.021

Rubtcova, M. V. (2009) Guidability and Power: The Relationship between the Concepts in Sociology of Management. Sociology of Power. Scientific and Sociopolitical Journal, 1, 57-59,177-183.

Rubtcova, M. V. (2015) Guidability as a Way to Organizational Innovations: Case Study of Three Types of New Organizations in Russia. Organizations \& Markets: Policies \& Processes eJournal. ERN: Authority \& Power. Retrieved from http://ssrn.com/abstract $=2576310$

Rubtcova, M. V. (2015). Corpus Linguistics in Sociological Research. Philosophy of Science eJournal, 8(11), March 26. http://ssrn.com/abstract $=2577167$

Rubtcova, M. V. (2015). How 'Cognitive Linguistics' Can Help/Improve the Pragmatic Explanations of 'Altruism' in Russian. Cognitive Linguistics: Cognition, Language, Gesture eJournal, 7(10). http://dx.doi.org/10.2139/ssrn.2571947

Rubtcova, M. V., \& Martianova, N. A. (2012). Institutional Altruism in Professional Practice: The Sociological Analysis of Professions of Robert K. Merton. Vestnik St. Petersburg State University. Ser. 12. Psychology, Sociology, Education. Issue 1, 152-158. http://dx.doi.org/10.2139/ssrn.2574295

Rubtcova, M. V., \& Martianova, N. A. (2013) Professionals and Clients: Struggle for Dominance in Conditions of Musical Inclusive Education. Historical, philosophical, political and legal sciences, cultural studies and art history. Theory and Practice. Tambov: Gramota, 11(37), Part II, 152-155. http://dx.doi.org/10.2139/ssrn. 2574549

Rubtcova, M. V., Martyanov, D. S., \& Martyanova, N. A. (2013). Professional and expert communities as subjects of management in the context of the knowledge society and deprofessionalization. Vestnik St. Petersburg University. Ser. 12. Psychology, Sociology, Education. Issue 1, 69-74. http://dx.doi.org/10.2139/ssrn.2574551

Rubtcova, M., Pavenkov, O., Pavenkov, V., \& Vasilieva, E. (2015a). The Language of Altruism: Corpus-based Conceptualisation of Social Category for Management Sociology. Asian Social Science, 11(13), 289-297. http://dx.doi.org/10.5539/ass.v11n13p289

Rubtcova, M., Pavenkov, O., Pavenkov, V., \& Vasilieva, E. (2015b). Representations of Trust to Public Service in Russian Newspapers during Election Time: Corpus-based Content Analysis in Public Administration Sociology. Mediterranean Journal of Social Sciences, 6(4), July.

Rubtsova, M. V. (2007). Manageability: Sociological theoretical analysis of notions. Sotsiologicheskie Issledovaniya, 12, 32-38.

Rubtsova, M. V. (2008). The Problem of Manageability Provision in Modern Organisations and Ways of its Solution. Izvestia: Herzen University Journal of Humanities and Sciences, 84, 211-217. http://dx.doi.org/10. 2139/ssrn.2575090

Rubtsova, M. V. V. (2011) Governmentability in interactions of subjects. Traditional and new practices. Sotsiologicheskie Issledovaniya, 2, 46-53

Rubtsova, M. V., \& Martyanova, N. A. (2014). Crisis of professional identity in the conditions of the market. Vestnik St. Petersburg State University. Ser. 12. Psychology, Sociology, Education. 2014. Issue 1, 177-182. http://dx.doi.org/10.2139/ssrn.2573870

Russian National Corpus. (2015). Retrieved from http://www.ruscorpora.ru/

Sanina, A. (2012). Competing for a citizen: "visible" and "invisible" forms of state identity in Russia. Journal of Eurasian Studies, 3(2), 126-146

Seddon, T. (1997). Education: Deprofessionalised? Or reregulated, reorganised and reauthorised? Australian journal of Education, 4(3), 228-246.

Segrestin, D. (2000). Sociology of the professions. Sociologie Du Travail, 42(2), 347-348.

Smelser, N. J. (1996). Social sciences and social problems - The next century. International Sociology, 11(3), 275-290. http://dx.doi.org/10.1177/026858096011003001

Sorokin, P. A. (1967). The Ways and Power of Love. Chicago: Beacon press.

Srnec, J. (2007). Metamorphoses of medical profession from the point of view of sociology. Ceskoslovenska Psychologie, 51(3), 319-321. 
Strekalova, N. D., Semenov, V. A., \& Rogova, G. I. (2014). Professional environment as a Factor of Professional Development of Tax Service Civil Servants. Administrative Consulting [Upravlencheskoe konsul"tirovanie], 2(62), 15-27.

Timmermans, St., \& Hyeyoung, Oh. (2010). The Continued Social Transformation of the Medical Profession. Journal of Health and Social Behavior, 51, 94-106. http://dx.doi.org/10.1177/0022146510383500

Toren, N. (1975). Deprofessionalization and its sources. A preliminary analysis. Sociology of Work and Occupations, 2(4), 323-327.

Vasilieva, E. A. (2011). State power mythology: a sociological aspect. Science and Education [Nauka i Obrazovanie], 3, 119-121.

Vasilieva, E. A. (2013). Theoretical Basis of analysis of the potential of social institution. European Social Science Journal, 1(9), 198-203

Volchkova, L. T., \& Pavenkova, M. V. (2002) Sociology of management. Theoretical principles. Sotsiologicheskie issledovaniya, 3, 141-144

Weber, M. (1981). Some Categories of Interpretive Sociology. Sociological Quarterly, 22(2), 151-180. http://dx.doi.org/10.1111/j.1533-8525.1981.tb00654.x

\section{Copyrights}

Copyright for this article is retained by the author(s), with first publication rights granted to the journal.

This is an open-access article distributed under the terms and conditions of the Creative Commons Attribution license (http://creativecommons.org/licenses/by/3.0/). 